Acta Theriologica 38 (2): 113 - 123, 1993.

PL ISSN 0001 - 7051

\title{
The influence of landscape spatial structure on small mammal movements
}

\author{
Jakub SZACKI, Joanna BABIŃSKA-WERKA and Anna LIRO
}

Szacki J., Babińska-Werka J. and Liro A. 1993. The influence of landscape spatial structure on small mammal movements. Acta theriol. 38: 113 - 123.

The present knowledge of the range of small mammal (field mice Apodemus agrarius (Pallas, 1771) and bank vole Clethrionomys glareolus (Schreber, 1780)) movements is discussed and data concerning long distance movements obtained by the authors are presented. Small mammals appeared to be much more mobile than it is commonly believed. Spatial distribution of movements is not random and some routes of movements can be recognized. Such routes are covered mainly by ruderal vegetation and dense bushes. Considerable mobility of small mammals found in the presented studies encourages to think over the present views on organization and regulation of populations.

Institute of Physical Planning and Municipal Economy, Krzywickiego 9, 02-078 Warsaw, Poland (JS, AL); Department of Game Management, Agriculture University of Warsaw, Rakowiecka 26/30, 02-528 Warsaw, Poland (JB-W)

Key words: small mammals, movements, routes, heterogeneity

1. Introduction

2. The range of small mammal movements in different landscapes

3. Movement routes of small mammals

4. Spatial pattern of small mammal mobility in heterogenous landscapes

\section{Introduction}

Over the last decades many papers were devoted to small mammal movements (e.g. Brown 1966, Stenseth 1983, Flowerdew 1985). They were dedicated mainly either to dispersal or to activity within home ranges. Dispersal has been studied as a phenomenon influencing organization and regulation of a population and movement distances have been disregarded. Data on movements within home ranges are not consistent. Usually, it is assumed that home ranges of small mammals are relatively small, below 1 ha (e.g. Wolton and Flowerdew 1985, Grüm 1988). Several authors, however, have found occasional cases of long-distance movements, much longer than usually assumed home range diameter (e.g. Crawley 1969, Furrer 1973, Clark et al. 1988). Such movements were identified as "sallies outside home range". Some data, however, suggest that long-distance movements 
of small mammals are common and actual range of movements is considerably greater than it was assumed previously (Andrzejewski and Babińska-Werka 1986, Liro and Szacki 1987, Szacki and Liro 1991). Data used for calculation of home range size were gathered mostly with the live-trapping method. This method does not seem to be suitable for studying small mammal mobility. The size of home ranges depends on a priori assumptions regarding shape, number of catches taken as a basis for calculation (Mares et al. 1980) and distances between traps (Gurnell and Gipps 1989). The presence of live-traps may inhibit movements of animals under study (Sheppe 1967). Moreover, grids of traps cover usually only a few hectares and long movements cannot be noticed. The use of other methods, e.g. tracking (Randolph 1973) or telemetry (Wolton 1985, Tew 1988), frequently discovers much longer distances of movements. Homing experiments also indicate that small mammals are able of traversing considerable distances in short periods (e.g. Jamon and Bovet 1987).

Thus, the knowledge on ranges of small mammal movements seems to be insufficient. Also, we know very little about directions and routes of their movements (Hansson 1987). It is an important obstacle to understand how small mammal populations function within large areas or on the landscape scale.

The aim of this paper is to present our recent results on small mammal movements against a background of existing literature.

\section{The range of small mammal movements in different landscapes}

In most cases it is assumed that the range of small mammal movements is relatively small and the diameter of their home ranges do not exceed $100 \mathrm{~m}$. However, some existing data suggest that small mammals are able to traverse much longer distances. Dickman and Doncaster (1989) report that bank voles and wood mice can move in an urbanized area as far as $500 \mathrm{~m}$. Clark et al. (1988) found, that the American species Reithrodontomys megalotis can cover distances up to $3200 \mathrm{~m}$. Wolton (1985) reported that wood mice could move up to $1030 \mathrm{~m}$ (males) or $810 \mathrm{~m}$ (females). Animals of this species covered distances of $1600 \mathrm{~m}$ during the night (Karaulin et al. 1976, after Wolton 1985) and Tegelström and Hansson (1987) found movements of common shrews as long as $4 \mathrm{~km}$ (during the winter on ice and snow). An even greater range of small mammal (Apodemus sylvaticus) movements was reported by Tew (1988): $2.5 \mathrm{~km}$ during the night and occasionally up to $4 \mathrm{~km}$. Pokki (1981) found that individual voles (Microtus agrestis) swam between sea islands covering distances up to $500 \mathrm{~m}$ in that way. Furthermore, homing experiments indicate that small mammals can traverse a few hundred meters in an hour (e.g. Jamon and Bovet 1987).

Also, our own studies with the use of coloured bait or oat grains as markers and snap-traps suggest that small mammals are mobile animals. Data in Table 1 indicate that a relatively large proportion of individuals move more than $100 \mathrm{~m}$ 
Table 1. Distances of small mammal movements in the suburban mosaic of habitats near Warsaw as revealed by studies with the method of snap traps and coloured bait (Szacki and Liro 1991).

\begin{tabular}{ccc}
\hline Distances $(\mathrm{m})$ & \multicolumn{2}{c}{ Number of individuals } \\
& A. agrarius & C. glareolus \\
\hline$<100$ & 78 & 13 \\
$101-250$ & 29 & 8 \\
$251-400$ & 23 & 5 \\
$401-550$ & 21 & 8 \\
$551-700$ & 17 & 4 \\
$701-850$ & 13 & 2 \\
$851-1000$ & 24 & 3 \\
$>1000$ & 37 & 12 \\
\hline
\end{tabular}

and in case of field mice there is no clear trend towards reduction of number of individuals with increasing distance. Similar results were obtained by $\mathrm{J}$. Babińska-Werka and R. Andrzejewski for bank voles and yellow-necked mice (unpubl.). Data in Table 2 show that maximal distances covered by small mammals under study were much greater than commonly observed ranges of movements. We have found also lack of differences in sex ratio, mean weight, and sexual activity between animals traversing long $(>100 \mathrm{~m})$ distances and the rest of the population.

Information on great mobility of small mammals is generally disregarded by the majority of authors, strongly attached to the still dominating paradigm of small and stable home ranges. In order to defend this paradigm new terms for long distance movements are introduced e.g. "sallies outside home ranges" (Stickel 1968, Wolton and Flowerdew 1985) and "life range" (Furrer 1973). In fact, a home range is a product of the human mind and thus it is not possible to define exact

Table 2. Maximal distances $(\mathrm{m})$ of small mammal movements in different landscapes.

\begin{tabular}{|c|c|c|c|}
\hline Landscape type & Species & Max distance & References \\
\hline Homogeneous forest & C. glareolus & 300 & Andrzejewski and Babińska-Werka 1986 \\
\hline Homogeneous forest & $\begin{array}{l}\text { C. glareolus } \\
\text { A. flavicollis }\end{array}$ & $\begin{array}{l}330 \\
452\end{array}$ & R. Andrzejewski and J. Babińska-Werka (unpubl.) \\
\hline Heterogeneous forest & $\begin{array}{l}\text { C. glareolus } \\
\text { A. flavicollis }\end{array}$ & $\begin{array}{l}480 \\
480\end{array}$ & R. Andrzejewski and J. Babińska-Werka (in prep.) \\
\hline Heterogeneous forest & C. glareolus & 800 & R. Andrzejewski and J. Babińska-Werka (unpubl.) \\
\hline $\begin{array}{l}\text { Suburbian mosaic of } \\
\text { habitats }\end{array}$ & $\begin{array}{l}\text { C. glareolus } \\
\text { A. agrarius }\end{array}$ & $\begin{array}{l}>1500 \\
>1500\end{array}$ & Szacki and Liro 1991 \\
\hline
\end{tabular}


borders of a home range. The calculated home range only points to some probability of meeting an animal in a given place.

The fact that small mammals are much more mobile than it is commonly believed is shown in our studies both by the distribution of distances covered by them and lack of difference between "long distance" wanderers and the remaining individuals. Great mobility seems not to be restricted to certain specific kind of individuals. Also in Wegner and Merriam (1990) study considerable mobility of small mammals in a farmland mosaic was shown and it was not possible to distinguish transients and dispersers from the rest of the population: very mobile animals not attached to any home ranges dominated there.

The method of coloured bait and snap traps applied in our studies does not allow to distinguish different categories of movements - whether it is mobility within home ranges or dispersal movement. Furthermore, most data were collected in late summer and autumn. However, some existing data for other than autumn seasons (Szacki and Liro 1991, R. Andrzejewski and J. Babińska-Werka, unpubl.) indicate long-distance movements so they are not necessarily connected to the autumn peak of dispersal. No matter what their nature, long distance-movements play a significant role in the landscape ecology of small mammals.

\section{Movement routes of small mammals}

We found the movement distances of small mammals to be much greater than it was previously assumed. This fact encourages to reconsider existing concepts of the functioning of small mammal populations on the scale of a landscape and to pay special attention to space-use of individuals. In order to understand the functioning of small mammal populations it is essential to learn directions and routes of individual movements as well as movement ranges.

In the theory of landscape ecology and in studies based upon the metapopulation theory one of the main assumptions of functional connectivity of demographic units is their mutual feeding and transfer of individuals among landscape elements (Forman 1983, Henderson et al. 1985, Merriam 1988, Opdam 1990). In most cases animals move along a network of ecological corridors what considerably increases the efficiency of habitat islands recolonization (Middleton and Merriam 1981, Forman and Baudry 1984). According to Forman and Godron (1981) an ecological corridor is a strip of land different from its surroundings and more or less similar to habitat islands which are attached to the corridor. It is one of three elements of a landscape structure apart from matrix and habitat islands (remaining in the agricultural landscape after clearing the forest) which ensures connectivity thus being of importance for the survival of metapopulations (Merriam 1984, Fahrig and Merriam 1985).

In the eighties ecological corridors were analyzed with respect to their spatial configuration and internal structure and population dynamics in a boundary 
between a corridor and the matrix and within a corridor (Forman 1981, 1983, Lefkovitch and Fahrig 1985, Szacki 1987, Merriam 1988, Dmowski and Kozakiewicz 1990). Also, attention was paid to behavioural responses of animals of different species avoiding each other within the corridor (see Merriam 1990). However, the primary role of corridors - transfer of individuals - is still poorly evidenced.

We have found in the course of the analysis of long-distance movements (more than $300 \mathrm{~m}$, mainly for field mouse) that movements starting in a point with coloured bait were multidirectional. Stations with coloured bait visited by rodents were located in different elements of the habitat mosaic: in mid-field afforestation, linear afforestation along roads, in large forested areas, and in patches of ruderal vegetation. Animals moved either within one habitat or between different ones, more or less separated from each other. Although animal movements were multidirectional it was possible to distinguish some tendencies in their distribution. In large, relatively natural areas of the Natolin Park and the Kabacki Forest (near Warsaw) more field mice moved out of than into the habitat and the directions of movements were not consistent with this species density gradient. The number of bank vole passages was too small for analysis and it was possible only to note that numbers of individuals entering and leaving the Natolin Park were similar. Fig. 1 presents the distribution of small mammal movements in autumn of 1986 and 1987 (Szacki and Liro 1991). Locating coloured bait in various habitats of a large study area (Liro and Szacki 1987, Szacki and Liro 1991) enabled us to recognize those individuals which moved between different elements of the landscape (Fig. 2). Some animals left forested areas moving to different elements
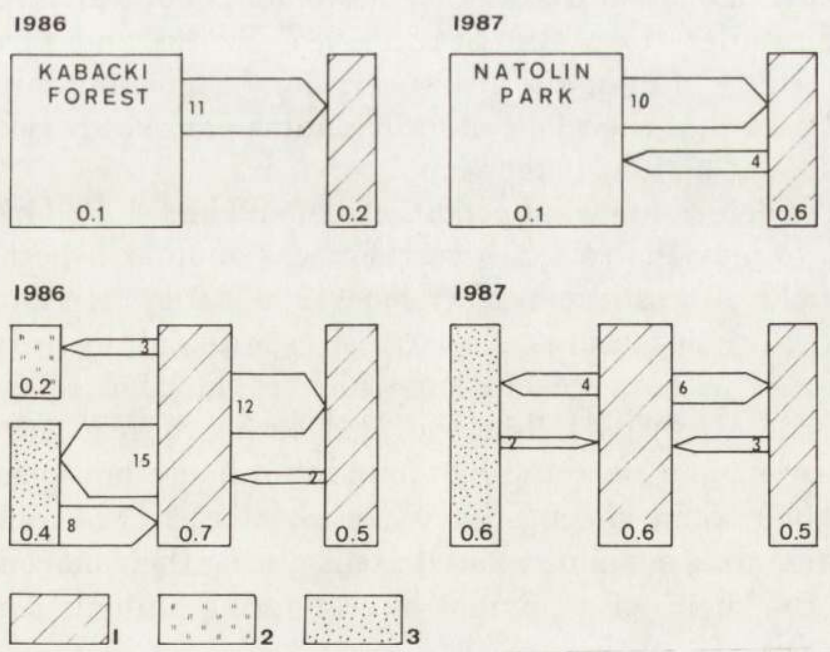

Fig. 1. Distribution of field mouse movements in the suburban mosaic of habitats (after Szacki and Liro 1991, modified). 1 - linear afforestations, 2 - meadows, 3 - ruderal vegetation. The width of arrows is proportional to the number of passages. Numbers inside arrows represent number of passages. Numbers inside rectangles representing habitats indicate density of field mice per 1 ha. 


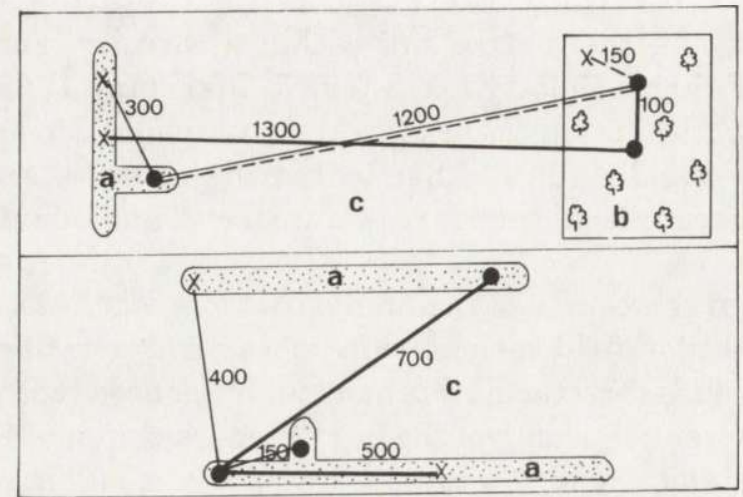

Fig. 2. Some examples of individual multidirectional movements of small mammals in the suburban mosaic of habitats (Szacki and Liro 1991). a - linear afforestations, b - the Natolin Park, c-meadows. $\mathrm{X}$-s represent the places on a line where given animals were captured and circles represent localities of the bait visited by the captured animal. Solid lines stand for field mouse movements and a dashed line for a bank vole.

of mid-field afforestation system and then returned. It points to penetrating the area rather than dispersal, i.e. leaving one habitat to inhabit another one.

The role of connectivity in population functioning in a landscape is one of the most important aspects of landscape ecology. It is based upon the assumption that the network of ecological corridors enables animals to cross the matrix isolating habitat islands, thus, helping to (re)colonize the isolated patches. The network of linear corridors is first of all the way for movements but also a reception habitat. Results of our studies (Liro and Szacki 1987, Szacki and Liro 1991) confirm considerable mobility of animals within corridors connecting forested areas. Our results also suggest that the range of individuals under study covers complex and integrated system of habitat patches and corridors.

An attempt to determine what conditions should be fulfilled by elements of the habitat mosaic to play the role of a corridor was another aspect of our study on strips of mid-field afforestation. Morrison (1986, after Merriam 1990) tried to determine characteristic features of a corridor experimentally by creating artificial corridors in areas without vegetation which could be a cover for wandering animals. Mice chose corridors that provided both overhead cover and cover at ground level. Lorenz and Barret (1990) found that house mice preferred wide and dense afforestation when moving. They also chose corridors being strips of high ruderal vegetation thus avoiding mowed areas during their movements. According to the authors the choice of a corridor by wandering animals depended on cover and food resources.

It was found in our studies, conducted in the suburbia of Warsaw (Liro and Szacki 1987, Szacki and Liro 1991), that also the internal structure is an important feature of a corridor. Some sections of trap lines ran through more or less 

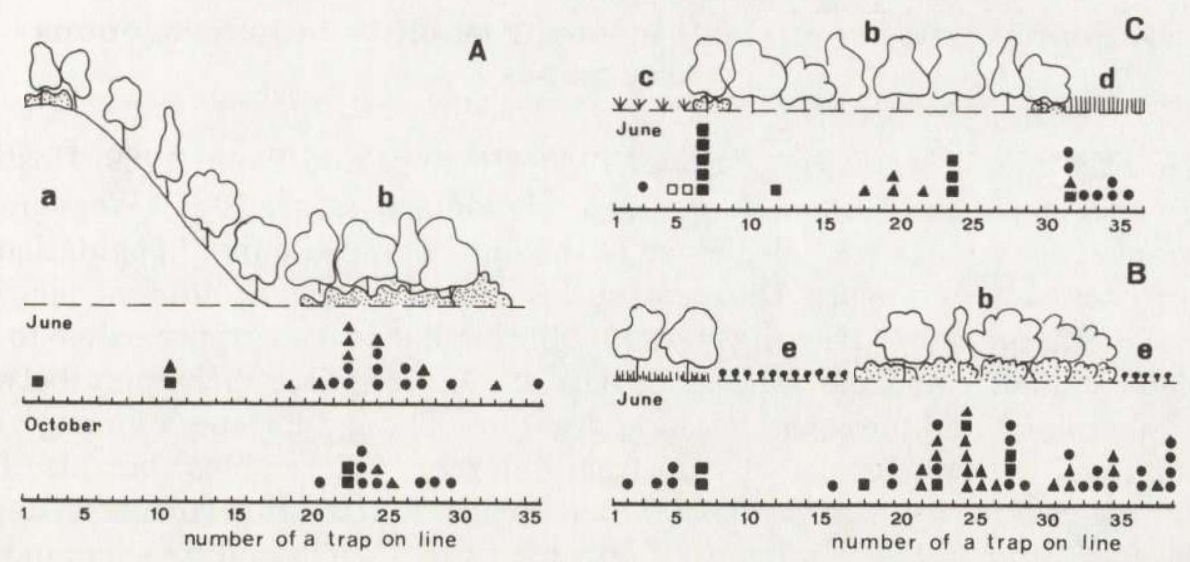

Fig. 3. The distribution of catches of small mammals along three exemplary traplines (A, B and C). Each small circle above the line represents one catch of field mouse, triangles represent catches of bank voles, filled squares represent catches of yellow-necked mice and unfilled ones - wood mice Apodemus sylvaticus. a - Warsaw escarpment, b - afforestation, c - ruderal vegetation, d - corn-field, e - field of potatoes.

homogenous habitats whilst other crossed different habitats (Fig. 3A, B, C). In both cases the distribution of catches along lines was uneven. Most of catches were recorded in rich ruderal vegetation and dense bushes $\left(\chi^{2}, p<0.05\right)$. The uneven distribution of catches along trap lines indicates that some distinct routes of movement exist, that is, some habitats are used by moving animals more often than others (it was found that there is a significant correlation between number of all animals captured in a given locality and animals with coloured bait captured there (A. Liro and J. Szacki, in prep.).

Existing linear barriers such as gravel roads and ditches were no obstacle to the movement of field mice and bank voles whereas a belt of single-family homes and a ploughed field presented barriers to movement; not a single case of passage through these obstacles was recorded (Liro and Szacki 1987). The problem of crossing matrix and the role of the matrix in a landscape was the subject of only a few studies. Wegner and Merriam (1990) noted common occurrence of Peromyscus leucopus (species typical for wooded areas) in fields. Catches of those animals were more numerous in fields than in poor woods. The occurrence of individuals in fields was unstable and depended on agricultural intensity and the state of plant cover. That species was not present in pastures and meadows. Hansson (1987) found considerable frequency of movements of forest rodent species along grassland links. In our studies we have recorded catches of Apodemus flavicollis in crop fields and in vegetable cultivations. Those results suggest the important role of the matrix in small mammal survival in a heterogeneous landscape. It seems that this role is still underestimated by the majority of ecologists. 


\section{Spatial pattern of small mammal mobility in heterogenous landscapes}

Recently many theoretical (Pulliam 1988, Hastings and Wolin 1989, Hastings 1990) and empirical (Geuse et al. 1985, Henderson et al. 1985, Wegner and Merriam 1990) studies were dedicated to the functioning of animal populations in heterogenous environments. Different authors have, however, different views on spatial heterogeneity. Hastings (1990) distinguishes two approaches to the problem: diffusion and patchiness, Taylor (1990) recognizes dichotomy between island-mainland and metapopulation approaches. Those differences among views of individual authors result not only from different "philosophies" but also from assuming various spatial scales for population functioning (to some degree "philosophy" and scale are related). If only a part of a patch and its surroundings are considered it is a classic source-sink pattern. When a single small patch or a few patches and some bigger ones are taken into account it is the habitat islands-mainland approach and finally when a whole set of local populations is considered it is a metapopulation approach. There are more differences between the two latter approaches: the presence of the permanent source of animals in the case of a habitat island-mainland approach and the extent of isolation. Individual populations in a metapopulation are by definition only partially isolated, habitat islands may be almost entirely isolated (e.g. populations inhabiting patches of habitats in cities). Certainly, those approaches are not completely exclusive.

Results of our studies are not consistent with any of the models mentioned above. In the case of the source-dispersal sink approach the existence of "donor habitats" (Hansson 1977) is assumed where some "worse" animals are forced to leave and end up in dispersal sinks. It was found in studies by Liro and Szacki (1987), and Szacki and Liro (1991) that the directions of small mammal movements were not consistent with the density gradient: animals moved among various habitats of different density in different directions (Fig. 1). Thus, it was not possible to distinguish dispersal sinks. Certainly, some habitats were less often visited by animals than others, e.g. in intensively cultivated meadows and fields small mammals were not being caught almost at all. However, the analysis of coloured fibers in animal intestines indicated that also those less suitable habitats are used by moving animals. As a considerable number of individuals moved freely among various habitats covering large distances applying the island-mainland approach was not possible either. Almost complete lack of isolation between individual patches as regards small mammals caused that it was not possible to apply metapopulation theory to interpret our results. Metapopulation theory is applicable in the case of coarse-grained (when individual territories are smaller than habitat patches) or hierarchical heterogeneity (Rolstad 1991). In case of fine-grained mosaics, local populations are not isolated in individual patches and the metapopulation model does not represent reality. Whether a given landscape is fine- or coarse-grained depends on the mobility of the considered species. For 
small mammals landscapes under study appeared to be fine-grained. The existence of stable metapopulations is possible when the connectivity between patches is ensured (Fahrig and Merriam 1985, Hansson 1991) but if isolation is too small the landscape is inhabited by one large population instead of a set of subpopulations forming a metapopulation. Our landscapes were inhabited by such large populations and individuals moved frequently among patches so that possible extinctions and recolonizations (those phenomena are primary features of a metapopulations) could not be observed. Geuse et al. (1985) wrote that some generalist and mobile - species may perceive a habitat mosaic as a whole. In case of our studies both field mice and bank voles (presumed to be less mobile) perceived the mosaic of habitats in the suburbia of Warsaw in this way. Thus, taking into account the possibility of covering by rodents considerable distances and crossing various environmental barriers great "minimum dynamic area" (Pickett and Thompson 1978, Henderson et al. 1985) should be assumed. It would cover the whole set of different habitats. Similar conclusions were drawn by Wegner and Merriam (1990).

In this context the question on the possibility of generalizating those findings arises. First, functioning of a population in a landscape may depend on the species considered. E.g. Szacki (1987) found that meadows surrounding a habitat island were an important barrier for bank vole movements and they were no barrier at all for wood mice and consequently populations of the two species responded to that habitat configuration in a different way. Generally, generalist species may perceive the fine-grained mosaic of habitats as a whole whereas more specialized animals may occur in local and partially isolated subpopulations. Second, the pattern of population functioning may be different in different types of landscapes. In a fine-grained mosaic individual patches may meet various animal needs and as different habitats are not distant there is a good reason to move between them. In a case of large and thus distant habitats the motivation to move may be much weaker. Third, the space use may vary between seasons of the year. It is especially true in case of agricultural landscapes where food resources change rapidly. Another problem is the scale. The problem is recognized theoretically by several authors (e.g. Wiens et al. 1986) but actually nobody seems to know what spatial scale should be used to study specific populations in a landscape. The study by Krohne and Burgin (1990) is one of the few exceptions.

Therefore, the question on the possibility of generalizating results of studies on animal populations in an ecological landscape is still unanswered and different models may be the best approximation of the reality, depending on the specific habitat configuration. That kind of a problem is not new in ecology. E.g. in case of problems related to population regulation Kikkawa (1981) wrote: "no general theory can explain the regulation of animal numbers". That belief should not, however, prevent from searching for general theories as such searching is the crucial aim of any science.

Acknowledgements: The authors thank reviewers for their critical comments. 


\section{References}

Andrzejewski R. and Babińska-Werka J. 1986. Bank vole populations: are their densities really high and individual home ranges small? Acta theriol. 31: 407 - 420.

Brown L. E. 1966. Home range and movement of small mammals. Symp. Zool. Soc. Lond. 18: $111-142$.

Clark B. K., Kaufman G. A., Finck E. J. and Hand S. S. 1988. Long-distance movements by Reithrodontomys megalotis in tallgrass prairie. Am. Midl. Nat. 120: 276 - 281.

Crawley M. C. 1969. Movements and home ranges of Clethrionomys glareolus Schreber and Apodemus sylvaticus L. in north-eastern England. Oikos 20: 310-319.

Dickman C. R. and Doncaster C. P. 1989. The ecology of small mammals in urban habitats. II. Demography and dispersal. J. Anim. Ecol. 58: 119 - 127.

Dmowski K. and Kozakiewicz M. 1990. Influence of a shrub corridor on movements of passerine birds to a lake littoral zone. Landscape Ecol. 4: $99-108$.

Fahrig L. and Merriam G. 1985. Habitat patch connectivity and population survival. Ecology 66: $1762-1768$.

Flowerdew J. R. 1985. The population dynamics of wood mice and yellow-necked mice. Symp. Zool. Soc. Lond. 55: $315-338$.

Forman R. T. T. 1981. Interaction among landscape elements: a core of landscape ecology. Proc. Int. Congr. Neth. Soc. Landscape Ecol., Veldhoven: $35-48$.

Forman R. T. T. 1983. Corridors in a landscape: their ecological structure and function. Ekologia (CSSR) 2: $375-387$.

Forman R. T. T. and Baudry J. 1984. Hedgerows and hedgerow networks in landscape ecology. Env. Mgmt 8: $495-510$.

Forman R. T. T. and Godron M. 1981. Patches and structural components for a landscape ecology. BioScience 31: $733-740$.

Furrer R. H. 1973. Homing of Peromyscus maniculatus in the channelled scablands of east-central Washington. J. Mammal. 54: 466 - 482 .

Geuse P., Bauchau V. and Le Boulengé E. 1985. Distribution and population dynamics of rodents in a patchy woodland habitat in central Belgium: preliminary results. Acta zool. Fenn. 173: $65-68$.

Grüm L. 1988. W sprawie pojęcia "areał osobniczy" i zasad porównywania jego charakterystyki. Wiad. Ekol. 34: 61 - 71. [In Polish with English summary]

Gurnell J. and Gipps J. H. W. 1989. Inter-trap movement and estimating rodent densities. J. Zool., Lond. 217: $241-254$.

Hansson L. 1977. Spatial dynamics of field voles Microtus agrestis in heterogeneous landscapes. Oikos 29: $539-544$.

Hansson L. 1987. Dispersal routes of small mammals at an abandoned field in central Sweden. Holarctic Ecol. 10:154 - 159.

Hansson L. 1991. Dispersal and connectivity in metapopulations. Biol. J. Linn. Soc. 42: 89 - 103.

Hastings A. 1990. Spatial heterogeneity and ecological models. Ecology 71: $426-428$.

Hastings A. and Wolin C. L. 1989. Within-patch dynamics in a metapopulation. Ecology 70: $1261-1266$.

Henderson M. T., Merriam G. and Wegner J. 1985. Patchy environments and species survival: chipmunks in an agricultural mosaic. Biol. Conserv. 31: $95-105$.

Jamon M. and Bovet J. 1987. Possible use of environmental gradients by homing wood mice, Apodemus sylvaticus. Behav. Process. 15: 93 - 107.

Kikkawa, J. 1981. Ecological paradoxes. Aust. J. Ecol. 2: 121 - 136.

Krohne D. T. and Burgin A. B. 1990. The scale of demographic heterogeneity in a population of Peromyscus leucopus. Oecologia 82: $97-101$.

Lefkovitch L. P. and Fahrig L. 1985. Spatial characteristics of habitat patches and population survival. Ecol. Model. 30: 297 - 308. 
Liro A. and Szacki J. 1987. Movements of field mice Apodemus agrarius (Pallas) in a suburban mosaic of habitats. Oecologia 74:438 - 440 .

Lorenz G. C. and Barret G. W. 1990. Influence of simulated landscape corridors on house mouse (Mus musculus) dispersal. Am. Midl. Nat. 123: 348 - 356.

Mares M. A., Willig M. R. and Bitar N. A. 1980. Home range size in eastern chipmunks, Tamias striatus, as a function of number of captures: statistical biases of inadequate sampling. J. Mammal. 61: 661 - 669 .

Merriam G. 1984. Connectivity: a fundamental ecological characteristic of landscape ecology. Proc. First Int. Sem. Meth. Landscape Ecol. Res. Plann. Roskilde University Center, Denmark. Vol. 1: 5-15.

Merriam G. 1988. Landscape dynamics in farmland. Trend. Ecol. Evol. 3: 16 - 20.

Merriam G. 1990. Ecological processes in the time and space of farmland mosaics. [In: Changing landscapes: an ecological perspective. I. S. Zonneveld and R. T. T. Forman, eds]. Springer, New York: $121-133$.

Middleton J. and Merriam G. 1981. Woodland mice in a farmland mosaic. J. Appl. Ecol. 18: 703 - 710.

Opdam P. 1990. Understanding the ecology of populations in fragmented landscapes. Trans. 19th IUGB Congress, Trondheim 1989: $373-380$.

Pickett S. T. A. and Thompson J. N. 1978. Patch dynamics and the design of nature reserves. Biol. Conserv. 13: $27-37$.

Pokki J. 1981. Distribution, demography and dispersal of the field vole, Microtus agrestis (L.) in the Tvarminne archipelago, Finland. Acta zool. Fenn. 164: 1- 48.

Pulliam H. R. 1988. Sources, sink and population regulation. Amer. Natur. 132: $652-661$.

Randolph S. E. 1973. A tracking technique for comparing individual home ranges of small mammals. J. Zool., Lond. 170: 509 - 520.

Rolstad J. 1991. Consequences of forest fragmentation for the dynamics of bird populations: conceptual issues and the evidence. Biol. J. Linn. Soc. 42: 149-163.

Sheppe W. 1967. The effect of livetrapping on the movements of Peromyscus. Am. Midl. Nat. 78: $471-481$.

Stenseth N. C. 1983. Causes and consequences of dispersal in small mammals. [In: The ecology of animal movement. I. Swingland and P. Greenwood, eds]. Clarendon Press, Oxford: 63 - 101.

Stickel L. F. 1968. Home range and travels. [In: Biology of Peromyscus (Rodentia). J. A. King, ed]. Special Publ. no 2 Am. Soc. of Mammal.: 373 - 411.

Szacki J. 1987. Ecological corridor as a factor determining the structure and organization of a bank vole population. Acta theriol. $32: 31-44$.

Szacki J. and Liro A. 1991. Movements of small mammals in the heterogenous landscape. Landscape Ecol. 5: $219-224$.

Taylor A. D. 1990. Spatial heterogeneity and ecological models. Ecology 71: $429-433$.

Tegelström H. and Hansson L. 1987. Evidence of long distance dispersal in the common shrew (Sorex araneus). Z. Saügetierkd. 52: $52-54$.

Tew T. 1988. The ecology of the European wood mouse (Apodemus sylvaticus) on British farmland. Abstr. of 2nd Int. Behav. Ecol. Conf., Vancouver: 103.

Wegner J. and Merriam G. 1990. Use of spatial elements in a farmland mosaic by a woodland rodent. Biol. Conserv. 54: $263-276$.

Wiens J. A., Addicott J. F., Case T. J. and Diamond J. 1986. Overview: the importance of spatial and temporal scale in ecological investigatios. [In: Community ecology. J. Diamond and T. J. Case, eds]. Harper and Row, New York: $145-153$.

Wolton R. J. 1985. The ranging and nesting behaviour of wood mice, Apodemus sylvaticus, (Rodentia, Muridae). J. Zool., Lond. 206: 203 - 224.

Wolton R. J. and Flowerdew R. J. 1985. Spatial distribution and movements of wood mice, yellow-necked mice and bank voles. Symp. zool. Soc. Lond. 55: 249 - 275.

Received 30 January 1992, accepted 28 April 1993. 